\title{
Methodologies Matter
}

From Axel Honneth's Reformism to John Dewey's Radicalism

Dirk Jörke and Philipp Wagenhals

\section{(2) OpenEdition}

\section{Journals}

Electronic version

URL: http://journals.openedition.org/ejpap/2126

DOI: $10.4000 /$ ejpap.2126

ISSN: 2036-4091

Publisher

Associazione Pragma

Electronic reference

Dirk Jörke and Philipp Wagenhals, « Methodologies Matter », European Journal of Pragmatism and American Philosophy [Online], XII-2 | 2020, Online since 14 December 2020, connection on 15

December 2020. URL : http://journals.openedition.org/ejpap/2126 ; DOI : https://doi.org/10.4000/ ejpap. 2126

This text was automatically generated on 15 December 2020.

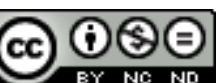

Author retains copyright and grants the European Journal of Pragmatism and American Philosophy right of first publication with the work simultaneously licensed under a Creative Commons AttributionNonCommercial-NoDerivatives 4.0 International License. 


\title{
Methodologies Matter
}

\author{
From Axel Honneth's Reformism to John Dewey's Radicalism
}

\author{
Dirk Jörke and Philipp Wagenhals
}

\section{Introduction}

1 Axel Honneth and John Dewey are both regarded as progressive thinkers of the (left-)Hegelian tradition. But when comparing their politico-economic demands, it quickly becomes clear that Dewey's political theory leads to more radical consequences: Whereas Honneth expresses reformist demands regarding minimum wage, Dewey, for instance, is not afraid to also raise the question of property and to suggest comprehensive nationalizations in the finance sector (Dewey LW 9: 77; LW 9: 287-90). Robert Westbrook (1991) thus rightly described the latter as a "democratic socialist." The central thesis of this essay is that this difference stems not only from historical factors but also from the methodological layout of their respective systems of thought. Honneth's method of normative reconstruction, which he develops particularly in Freedom's Right, has frequently and convincingly been criticized as being too affirmative. The point of our argumentation shall be that it is precisely Dewey's problem-solving approach that offers an alternative to Honneth's reformism. This comes as a surprise at first glance, insofar as Dewey's instrumentalism and experimentalism can easily be misunderstood as overly detailed conformist thinking and has been interpreted as such, for example by Max Horkheimer (2013 [1947]: 27-37). In comparison to this, we aim to illustrate the at least potential radically transformative implications that are attached to Dewey's problem-solving oriented way of thinking by contrasting it with Honneth's agenda of normative reconstruction. We are not concerned with the question of which method is more "radical" per se, but rather with showing that Dewey's method of problem-solving can lead to more radical political consequences under certain circumstances that need further elaboration. Nor are we concerned with the fundamental question of whether, and if so to what extent, radical reforms are in themselves better than gradual reformism. Rather, we are interested in showing that there may be problematic situations in which more radical changes are necessary in order to achieve democratic values, including those that 
affect a society's normative foundations, such as the legitimacy of private property. "Radical" means for us the aim to change some of the fundamental ordering principles of the society, e.g. the structure of ownership.

2 Two threads of discussion spanning the last two decades within Critical Theory will serve as the backdrop for this essay. The first of them is Critical Theory's increasing openness towards Dewey's pragmatism, thus turning away from the overly eager prejudgment by the Frankfurt school's first generation. Honneth himself (1998a; 1998b) made a valuable contribution in this context early on by granting Dewey's philosophy an increasing amount of space in his own reflections - even if, according to our thesis, he does not fully acknowledge its possibilities (apart from Honneth e.g. Hartmann 2003; Särkelä 2017; Jaeggi 2018). The second thread of discussion consists of the numerous publications especially from around the 2010s (e.g. Jaeggi \& Wesche 2009; Forst et al. 2009; Stahl 2013; Freyenhagen 2017; Jaeggi 2018) and their reflection on critical methodology, to which Honneth's Freedom's Right (2014) and its presentation of the method of normative reconstruction contributes as well. But in these methodological debates the potential of pragmatism is not, or with regard to Jaeggi (2018) not sufficiently, acknowledged. Although we will mainly deal with Honneth's methodology, in the end we will also briefly discuss Rahel Jaeggi's appropriation of Deweyian themes. Even though Jaeggi avoids Honneth's central methodological weaknesses, her reading of Dewey, too, remains flawed because her adaption of Deweyian themes in her materialistic-pragmatist account of progress still neglects Dewey's potential for critical theories.

3 Against the backdrop of growing interest in Dewey's thinking and the methodological reflection of Critical Theory, it is even more regrettable that Dewey's reflections on methodology have until now - as is the case with Honneth, who only eclectically resorts to the former's notion of problem(-solving) - barely stirred interest in the field of Critical Theory or still get dismissed as ultimately being inadequate in favor of a more Hegelian account (Jaeggi 2018). It seems as if the old reservations of Critical Theory that have since been presented more than once as outdated and misguided (e.g. Brunkhorst 2001; Särkelä 2018) have in this regard still not been completely overcome. ${ }^{1}$ We therefore consider a rigorous examination of Dewey's method to be of even greater importance - not only because of its compatibility with Critical Theory but also because we believe that his method proves to be superior especially in comparison with Honneth's normative reconstruction.

4 First, we shall illustrate the main features of Honneth's normative reconstruction and discuss the criticisms his suggestions receive. The second part takes up Honneth's reaction to this criticism as well as his adaptation of Dewey's experimentalism, claiming that Honneth's reception of Dewey does not tap the latter's full potential. The third section will focus in due briefness on Dewey's orientation towards democratic socialism. This part aims to showcase the substantial difference between Honneth's gradualism and Dewey's radicalism. Thus, we will look more intensively into Dewey's method of problem-solving activity in part four of this essay. In this context, Dewey's philosophy of the "creativity of action" (Joas 1997) opens up the perspective of a fundamental reorganization of social institutions. The fifth and last part of this essay serves to demonstrate why Dewey's method proves to be superior, especially in light of the challenges democracy faces today. 


\section{Honneth's Normative Reconstruction}

Between Honneth's earlier and later works, one cannot only recognize a conceptual shift from the notion of recognition to that of (social) freedom, but also a methodological change resulting in his method of "normative reconstruction" as he lays it out on the first pages of Freedom's Right (Honneth 2014: 1-11). His methodological reflections begin with a far-reaching diagnosis of the deficits of the currently dominant Kantian-idealist theories of justice. For Honneth, their dominance is closely connected to the history of the reception of Hegel's philosophy of right. The fact that the latter is predominantly regarded as conservative - in Honneth's words, "the somewhat primitive idea that given institutions must be given an aura of moral legitimacy" (Honneth 2014: 1) - led, says Honneth, to the current dominance of the Kantian-idealist theories in the first place. In contrast, Honneth's method of normative reconstruction pursues a goal that is partly based on Hegel's philosophy of right, namely to "develop the principles of social justice by means of an analysis of society" (Honneth 2014: xii). Consequently, Honneth not only strives to overcome the idealist deficit but - just as Hegel - aims to avoid the separation of empirical social sciences and normative philosophy. In order to obtain an updated version of the Hegelian scheme, it is, however, necessary to overcome the latter's "idealistic monism" (Honneth 2014: 3). Given the horrors of the past two centuries and considering materialist insights in philosophy, Honneth thus wants to build on Hegel, but from the standpoint of changed social circumstances and conditions of philosophical argumentation.

6 In order to develop the project of a theory of justice linked to Hegel in the style of social analysis, Honneth formulates four central premises for such a methodology (Honneth 2014: 3-11):

1) The reproduction of societies is tied to the conditions of a common orientation towards central values: Honneth formulates this premise with reference to Parsons, who states that values get incorporated into other subordinated social segments by ways of the cultural system and in the shape of role expectations, commitments and ideals.

2) The notion of justice is not independent of these values: Those values forming the conditions of reproduction for the respective society will serve as moral points of reference. Honneth thus envisions an analysis with an immanent starting point, and by doing so, he is setting himself apart from the Kantian-constructivist projects of Habermas and Rawls. This is the moment the method of normative construction takes effect: "This procedure implements the normative aims of a theory of justice through social analysis, taking immanently justified value as a criterion for processing and sorting out the empirical material." (Honneth 2014: 6).

3) Honneth emphasizes that society may not be regarded as an "already sufficiently analysed social reality itself" (Honneth 2014: 7) to which the immanently mapped-out principles will yet again be applied from the outside. Instead, the process of normative reconstruction aims at designating and characterizing especially those social spheres that guarantee the realization of the above-mentioned general values - in Hegel's words, the "ethical life." This shall serve to draw attention to even those institutions and practices that are otherwise marginalized. 
4) The process of normative reconstruction must offer an opportunity for critical application: What is criticized is that existing institutions and practices could be presenting certain values in an even more encompassing way.

7 By means of these four principles, Honneth intends to reconstruct the "moral grammar" (Honneth 2014: 127) of modern societies. His "initial premise" (Honneth 2014: vii) for this is that in modern, liberal societies all values can be subsumed under that of individual freedom. The notion of freedom is of such great interest to Honneth at this point because he recognizes in it the potential to mediate between the level of the individual and that of the social order. According to Honneth, modern societies can only rely on the notion of freedom, understood as "the autonomy of the individual" (Honneth 2014: 15), in order to justify certain institutions being worthy of recognition. In this context, the normative reconstruction of central social values functions as an important part in Honneth's project of filling a lacuna in his earlier works: Through the interplay of the notions of freedom and recognition, Honneth's theory is liberated from its intersubjective corset ${ }^{2}$ and in addition extended towards a more comprehensive understanding of social practice ("gesellschaftliche Praxis," Lepold 2017: 291), based on the assumption that society is understood as an interplay of spheres of action. Honneth distinguishes between two types of spheres of action, within which he normatively reconstructs the respective principles of justice: Right and morality belong to the mode of the "possibility of freedom"; personal relationships, market economy, and democratic public to that of the "reality of freedom" (Honneth 2014: 66). Within each sphere the value of personal freedom will unfold itself in its respective context-specific variations.

8 At this point, the question arises whether Honneth's commitments to an immanent method threaten to eventually slide into an optimism regarding the developmental history and tendencies of modern societies that is lacking further substantiation (and, in our view, cannot be further substantiated). For that reason, Frank Nullmeier (2013) brings forward the compelling argument that, in order to tell the story of the progress of modern institutions, Honneth circumvents this dilemma by relying on a quasiexternal position towards these institutions, which is established by way of retrospection. When Honneth constructs a history of development by means of retrospective criteria, these criteria thereby run the danger of turning into quasiexternal standards insofar as the point of their constitution and that of their application are too far from each other and, hence, become unrelated. This is the case because Honneth evaluates modern institutions with particular weight to their origination, the zero point of reconstruction. Honneth attributes too much weight to this phase in his method, if he assumes that modern institutions and practices qua being "the outcome of a centuries-long learning process" (Honneth 2014: 17) must be fundamentally accurate and of holds a tendency to fall back into a certain form of idealism as he blends together the factual and the ideal in his normative reconstruction, thus becoming "optimistic to the extreme" (Ng 2019: 805). ${ }^{3}$ Elements of conflict, which still arise from the play of recognition and disrespect in Honneth's earlier works (Honneth 1995: 131, 160), are woefully absent in his normative reconstruction when he claims that the "fact that subjects actively preserve and reproduce free institutions is theoretical evidence of their historical value" (Honneth 2014: 59). Clearly, the mere fact that subjects participate in social institutions does not 
entail their justification, as subjects can reproduce them for many reasons without considering their legitimacy.

Honneth's own aspirations as a scholar of Critical Theory are, of course, not simply "to analyse factical relations" (Honneth 2014: 128). His fourth methodological principle clearly states that the process of normative reconstruction must offer the possibility of critical application: Such a mode of criticism accordingly assumes that a moral institution could represent certain values in an even more encompassing way. Finally, normative reconstruction aims to follow "the historical development of each of these social spheres, the degree to which the understanding of freedom institutionalized within them has already been socially attained" (Honneth 2014: viii). He consequently assumes that existing institutions already guarantee, at least to a certain point, the type of freedom he has in mind - and thus remains affirmative to this extent. On the other hand, in his reconstruction of the three social spheres of freedom, Honneth in fact not only aims to point out their normative content but also examines intensely the "misdevelopments" (Honneth 2014: 128) within each sphere. According to Honneth's understanding, institutions can produce a "surplus of validity" (Honneth 2003: 150) which adds a critical impetus to his theory. Instead of bringing forward criticism from the outside, as for Kantian-influenced scholars, Honneth's approach is thus an immanent criticism of concrete institutions and their practices.

This critique is carried out in two steps: "These institutions of recognition within which subjects can achieve social freedom must be designed before the subjects, in a further step, come to a considered position on that order." (Honneth 2014: 59). If one takes seriously this second step, then it is also essential for Honneth's understanding of freedom to submit those institutions warranting freedom to a continuous, critical examination regarding the extent to which the values they represent are realized. At this point, however, opinions diverge regarding the degree of criticism that Honneth's method allows. Nullmeier (2013: 23), for example, holds that Honneth's approach still does, in principle, allow for radical criticism. ${ }^{4}$ Contrary to Nullmeier's conclusion we believe that, firstly, Honneth's gradualism is indeed problematic and that, secondly, Honneth's methodology in fact does not allow for any form of radical criticism. But why should mere reformism be a problem; why do we think that from a democracy theory perspective sometimes more radical changes are necessary?

11 The shortcomings of Honneth's gradualism are especially evident in his normative reconstruction of the market sphere. Contrary to Honneth's claims, the market does not in fact constitute a sphere of social freedom in the sense that it must be doubted whether the market can really produce purely intrinsically its own moral and ethical foundation since, for instance, central market principles conflict with moral and ethical prerequisites of social freedom. According to Timo Jütten (2015), a market economy requires that employers exercise a certain, often implicit form of dominance over their employees. Only through the implicit threat of unemployment and poverty do employees stick to their designated roles. Jütten (2015: 192) convincingly claims that this logic of the functioning of the market as well as the motivational incentives like fear and greed resulting from it are incompatible with the concept of social freedom, casting severe doubt on the question of how far the social institutions of the market really contribute to social freedom or if they do not rather undermine it at least at some points. 
This is not an accidental misdiagnosis, but is founded on the fact that normative reconstruction, in the shape that it takes in Honneth's work, does not allow any form of radical criticism, defining the latter as "all forms of critique that invoke norms that are not (yet) underlying existing, reproductively relevant social institutions" (Schaub 2015: 108); Karen Ng goes even so far as to characterize Honneth's model as "potentially ideological" (Ng 2019: 811). That is because the method of normative reconstruction is, in principle, unable to reflect fundamental "misfits" (Schaub 2015: 125) between norms and institutions in an adequate way. But when taking the Frankfurt School project of immanent critique seriously, social criticism should allow, though not in an external fashion, for a perspective that transcends and fundamentally transforms existing norms (see Jaeggi 2018, ch.6). Honneth's inaptitude for radical criticism may already have been rooted in his understanding of immanence - as has been shown by the criticism based on Nullmeier - and cannot be properly understood without the latter; but it is necessary to also consider its consequences beyond internal theoretical contradictions. Honneth's normative reconstruction does indeed capture so-called "misdevelopments"; 5 but because these are only gradual and not principled deviations, his method is not only unable to adequately capture fundamental dysfunctionalities, but also runs the risk of obscuring problems that go beyond such mere gradual deviations.

\section{Honneth's Half-Hearted Reception of Dewey's Experimentalism}

13 The Idea of Socialism is Honneth's reaction to the reproach that he argues too affirmatively in his reflections about market and democracy in Freedom's Right. In this work, Honneth aims at a reformulation of socialism, which he aligns with his concept of social freedom. Honneth chooses the early socialism of Owen, Saint-Simon, and Fourier as the point of departure, whose concepts, according to Honneth, result from the widening capitalist market which simultaneously hindered the principles of freedom and equality promised by the revolution:

Viewed from this perspective, the socialist movement has always been based on an immanent critique of the modern, capitalist social order; it accepts the latter's normative bases of justification - liberty, equality and fraternity - but argues that these values cannot be fully reconciled with each other as long as liberty is not interpreted in a less individualistic and more intersubjective manner. (Honneth 2017: 13)

14 In order to free socialism as a "universalizable substitute" from the roots of industrialism, Honneth strives to revive it in its "post-Marxist form" (Honneth 2017: 57f.). For Honneth, the most important task of updating socialism lies in overcoming the equation of the market economy and capitalism tracing back to Marx, in order to find free spaces for alternative approaches to the market economy. Honneth argues that socialism's fixation on a centrally-planned economy as the only suitable means must be overcome as quickly as possible and, instead, replaced by an "experimental market economy" following Dewey (Honneth 2017: 58f.). For this, Honneth identifies three possible models: 1) a free market in the style of Adam Smith; 2) unions of free producers anchored in civil society; and 3) the market-socialist idea of a democratically-legitimized state economy. According to Honneth, these models are to be regarded as coequal at first; only a renewed socialism would later have to 
experimentally examine which model better implements social freedom within the economic sphere and promises real progress. For this kind of assessment, Honneth borrows Dewey's idea of removing barriers that hinder communication and interaction to serve as a standard of evaluation:

Instead, socialism must be viewed as the specific modern articulation of the fact that in the course of history and on the basis of varying social circumstances, new groups constantly seek to draw public attention to their own demands by attempting to tear down barriers to communication and thereby expand the space of social freedom. (Honneth 2017: 65)

Honneth further argues that this may not remain a purely theoretical reflection: Instead, it would be necessary for various elements to be "test[ed] under real conditions," while socialism would serve as an "internal archive" to collect records of already undertaken experiments (Honneth 2017: 70). In fact, Honneth identifies empirical evidence for the two alternatives to a capitalist market, proving their successfulness. This evidence ranges from the social legislation of the early 20th century to minimum wage legislation to Canadian solidarity funds for employees and Basque cooperatives. Honneth thereby rejects the ties of traditional socialism to a revolutionary subject like the working class. The progressive element rather appears in "trace elements of desired progress" (Honneth 2017: 73) of concrete institutional achievements, into which an expansion of social freedom had been irrevocably embedded. But at this point, too, the character of Honneth's formulated criticism and his suggestions based on political realism remain "gradual rather than categorical" (Honneth 2014: 9). Even though by including Dewey's experimentalism Honneth certainly adds a dynamic element to his method of normative reconstruction, we maintain that he still remains too strongly rooted in an excessively restrained reformism. Characteristic of the limits of gradualism are the examples that Honneth cites in The Idea of Socialism, e.g., the already mentioned social legislation at the beginning of the 20th century or the introduction of minimum wages. Without wanting to belittle these achievements, it is becoming clear at present that such reforms can do little to counter the inequality dynamics of global capitalism (see Piketty 2020).

Against this backdrop it is even more disappointing that Honneth does not examine Dewey's substantial contributions to democratic socialism. These contributions are far more radical and do not exhaust themselves in sheer gradualism. Instead, Dewey questions the fundamental structures of modern capitalist societies. But Honneth does not follow Dewey down this path. One reason for this might lie in the fact that the latter's demands, e.g., for a socialization of key industries and banks or a fundamental redistribution of private property appear obsolete to Honneth in light of the realsocialist experiments - a view we do not share. The topic of what is to follow, however, is of a different nature. Rather, we hold that Honneth cannot go beyond an ultimately conservative gradualism due to methodological reasons. In The Idea of Socialism, Honneth refers back to the method of an "immanent critique of the modern, capitalist social order" (2017: 33), in the same way as he reconstructs the history of socialism at large according to his own social-philosophical premises (e.g. ibid.: 18, 23, 36). Honneth's gradualism, which becomes evident in formulations like "experiments in introducing change in capitalist societies" (Honneth 2017: 26) as well as in his undifferentiated defense of "[1]iberal rights to freedom" (Honneth 2017: 35-6), differs considerably from Dewey's radical new interpretation of such liberal rights to freedom. The latter's undertaking in writings such as Individualism. Old and New (1930) or Liberalism and Social 
Action (1935) in fact consists of characterizing the ideals of individual as well as social freedom in a new way, in order to adapt them to a changed social reality. Dewey's intention is to overcome a problematic situation, in which old ideals can no longer fulfill their promises. An essential part of this is questioning the liberal right of property, whereas Honneth tends towards overly careful formulations, such as: "the decisive question remains whether the gradual emancipation of workers can only be achieved by the expropriation of private property or whether this emancipation is reconcilable with existing forms of ownership." (Honneth 2017: 70). As we aim to show below, Dewey's radicalism is fundamentally linked to his concept of inquiry and his philosophy of problem-solving. But beforehand, we shall briefly point out the substantial differences to Honneth.

\section{Dewey's Democratic Socialism}

17 In The Ethics of Democracy (EW 1: 227-49), his first contribution to democratic theory, Dewey already underlines that democracy may not be limited to the sphere of politics. He claims that only when the democratic ideal is achieved in almost all social sectors, all preconditions for individual as well as collective freedom will be fulfilled. Accordingly, at the end of his essay, Dewey pleads for a democratization of the economy. For him, democracy is "not in reality what it is until it is industrial, as well as civil and political" (EW 1: 246). Throughout his life, Dewey was convinced that a functioning political democracy requires a comprehensive democratic culture reaching beyond the sphere of the immediately political. For this reason, he criticizes especially the oligarchic conditions of the economic sector and calls for an extensive reform of capitalism. He most notably pleads for a progressive income tax, the expansion of protection through the welfare state and an increase of state economic activity, especially in the areas of basic public services and infrastructure (e.g. LW 9: 287-90; see also Westbrook 1991). Until the end of the 1920's Dewey was convinced that a democratization of capitalism could be reached first and foremost through the transfer of scientific methods into the economic sector and through advisory processes in society as a whole. In Reconstructions in Philosophy, Dewey thus recommends transferring of the scientific method to the field of politics and morality. The idea of a scientization of politics, however, finds its clearest expression in The Public and Its Problems, his main work in the field of political theory from 1927. Although hints towards the limits of property rights and thus to the possibility of a radical transformation of society are scattered throughout, the belief predominantly expressed in this work is that the problems of the public can be solved via a deliberative path, through "improvement of the methods and conditions of debate, discussion and persuasion" (LW 2: 365). On the whole, Dewey was at that time rather a liberal or social democratic thinker than someone who advocated a radical transformation of society.

During the Great Depression, however, Dewey grew more and more aware of the fact that a "great community" as well as his understanding of deliberative democracy could only prosper in a place where the economy is under democratic control to the largest extent possible. As Marc Stears demonstrates convincingly, Dewey grew more and more radical, despite never giving up on the ideal of deliberative democracy, and "his views as to how such a democracy could be built, by whom, and when, all radically changed as the Depression years progressed" (Stears 2010: 86; see also Bordeau 1971). 

well as in many articles which Dewey wrote during the 1930s he again and again argued that American society is split into a powerful economic and political elite and a mass of ordinary citizens, and for many amongst them, the fundamental democratic promises exist only on paper. The influence of industry and capital is simply too strong, and the possibilities of shaping decisions through democratic will-formation are very limited. The consequences that follow are political apathy and the feeling of being unable to influence political and social decision-making. According to Dewey, this is the exact opposite of individuality and freedom. If the individual is unable to shape her lifeenabling environment at all or to a sufficient degree, she is no longer free. Behind his criticism stands his ideal of individual growth as a core principle of a democratic community. Dewey's main point of argumentation is that in a capitalist society, individual growth or self-realization is impossible for a large part of the population. For that reason, Dewey argues that an individualism focusing only on individual rights last but not least the right of property - and serving the powerful few must be replaced by a new understanding of freedom, namely "effective power to do specific things" (LW 11: 360). To ensure this effective power for all citizens, intervention in the economy is necessary:

A stable recovery of individuality waits upon an elimination of the older economic and political individualism, an elimination which will liberate imagination and endeavor for the task of making corporate society contribute to the free culture of its members. Only by economic revision can the sound element in the older individualism - equality of opportunity - be made a reality. (LW 5: 75-6)

It is quite evident that Dewey draws the consequences resulting from his earlier criticism of the "religious idealization [...] of private property" (LW 2: 341). Property rights are nothing but an instrument, an "end-in-view" that has to be re-examined once it no longer reaches its goals. In days past, strong personal property rights served the many, whereas today they only secure the privileges of the rich and thus should be replaced by a different conception of property (see Betz 1978: 34). According to Dewey, the main criterion for a just society is not the protection of individual property, as in classic liberalism, but the equal opportunity for growth. If absolute property rights are working against this goal, they are no longer "true" and must be replaced by better institutions. Consequently, Dewey argues in Liberalism and Social Action: "The people will rule when they have power, and they will have power in the degree they own and control the land, the banks, the producing and distributing agencies of the nation." (LW 9: 77).

21 This leads to the question of a concrete configuration of democratic socialism. On the one hand, Dewey still clings to his faith in collective intelligence and scientific methods and distances himself from the Marxist doctrine of class struggle. He furthermore unequivocally rejects the use of force - at least up until this point, as shall be seen later. A complete democratic society, in which "effective power" is widely spread, can only be achieved through democratic means. For this purpose, Dewey distinguishes between a bureaucratic "planned" society and a democratic "planning" society: "The former required fixed blue-prints imposed from above [...] The latter means the release of intelligence through the widest form of cooperative give-and-take." (LW 13: 321). It remains unclear, however, how exactly Dewey imagined the implementation of this model of a democratic planning society. He formulated an abstract ideal rather than spelling out an institutional arrangement (Westbrook 1991: 457). 
It is nevertheless possible to identify four crucial components of democratic socialism that appear again and again in Dewey's writings of the 1930's (see also Bordeau 1971). The first aspect continues to consist of the combination of scientific expertise and the participation of citizens to the largest extent possible; Dewey was against a pure sovereignty of experts. For this purpose, he advocated fundamental reform of the education system, not least of all with the goal of an education for democracy to the largest extent possible. The second aspect designated the socialization of essential areas of the economy, especially the sectors of infrastructure, banking, and heavy industry including mineral resources. Thirdly, Dewey sympathized with Jefferson's idea of a ward system, a form of self-government and economic management limited to small areas that are as local as possible. Fourthly, Dewey took up the idea of a guild socialism as developed by D.H. Cole. What remained unclear, however, was the nature of the relationship between state regulation and the individual, local cooperatives, because the local units would be unable to hold their ground entirely without the use of force. This points to the unsolved problem regarding the transformation of a capitalist society into a democratic-socialist one: In light of the power structures often bemoaned by Dewey and the corruption of large political parties, the established institutions could not be employed to induce the hoped-for transformation. On the one hand, this prompted Dewey to pursue the founding of a new, third party, the League for Independent Action, which was to establish a popular alliance between workers, farmers and the lower-middle class. He was furthermore active in the Peoples' Lobby, an organization for civil society striving for the development of an alternative public (Lee 2015). On the other hand, however, he was aware that more radical means were equally necessary. Even though Dewey formulates this notion very carefully, he comes to the conclusion that use of force might be legitimate in at least one situation, this being the case when a minority rejects the majority's democratic will for radical change and "refuses by force to permit the method of intelligent action to go into effect" (LW 11: 61). In this scenario, he was particularly thinking of coercive instruments of the state. Especially if a minority is able to make use of the state apparatus to protect their privileges, democratic practice may also be "buoyant, crusading and militant" (LW 11: 299), as he explained in Democracy is Radical (see also Livingston 2017). Thus contrary to the wide-spread equation of pragmatism and piecemeal social reform, Dewey pleaded for a fundamental transformation of capitalist society, in order to create a social base for a new and more democratic liberalism: "It follows finally that there is no opposition in principle between liberalism as social philosophy and radicalism in action, if by radicalism is signified the adoption of policies that bring about drastic, instead of piecemeal, social change." (LW 11: 293).

In the following section we would like to develop the thesis that Dewey's radicalism stems from his methodological reflections, both with respect to his political demands as well as regarding the means to achieve them.

\section{Dewey's Methodology of Problem-Solving}

The point of departure for Dewey's methodological reflections is the naturalistic assumption that, throughout their lives, human beings will encounter problematic situations. According to Dewey, a problematic situation is characterized by the appearance of an unforeseen element, the failure of customary actions, or the presence 
of a conflict between people or between different goals that cannot be achieved simultaneously.

How can a problematic situation of this kind be overcome? Aside from ignoring the new situation or simply sitting it out, there are two fundamental possibilities: one can select an alternative course of action at random or follow a method of thinking which increases the chances of solving the problem. Dewey designates the latter as the scientific method or the method of intelligence. The role models to which he looks are the experimental natural sciences, whose success he traces back to two factors: Firstly, they abandoned the search for certainty; unchangeable entities or the divine being are no longer the focus of their considerations. They rather attempt to unlock nature's secrets by actively influencing the object of research and by experimenting with different forms of investigation. According to Dewey, however, it is not only this experimental approach that vouches for the successfulness of natural sciences. Beyond that, it is the cooperation of the "scientific community," which enables continuous progress in the creation of knowledge through the exchange and discussion of hypotheses. In other words, herein is shown the instrumental dimension of communication.

For the following elaborations, two aspects are central. Firstly, Dewey links his model of intelligent problem-solving to the idea of growth. Each time a conflict gets resolved creatively, something new comes into existence. This new element, however, can in turn become problematic itself after a certain amount of time, so that a new problematic situation ensues. According to Dewey, a process like this can neither be completed nor can the direction of this growth be predicted. More important, however, is that the idea of growing experience provides Dewey with a criterion for the assessment of problem solutions, because the latter must not block a further growth of experience - a rule that is valid in an egalitarian sense. Secondly, Dewey advocates transferring this method of intelligent problem-solving, which he also calls "inquiry," to areas of morality and politics, that is to say to those areas that regulate social life. His conviction is that moral, social, and political problems admit of intelligent solutions. Correspondingly, he hopes for an improvement of social institutions through application of the experimental method, which for him means, in accordance with his theory of science, an engagement with concrete problems and a collective search for creative problem solutions.

For Dewey, this means in particular that thought taboos in the areas of morality and politics are broken up, that values and institutions are no longer understood as unchangeable principles but as instruments to achieve certain purposes that are changeable on their part: "The general adoption of the scientific attitude in human affairs would mean nothing less than a revolutionary change in morals, religion, politics and industry. [...] The scientific attitude is experimental as well as intrinsically communicative. If it were generally applied, it would liberate us from the heavy burden imposed by dogmas and external standards." (LW 5: 115). He summarizes this course of action under the term social inquiry. However, Dewey needs to be protected from a common misunderstanding that he abetted himself through the rather undifferentiated use of the expression scientific method. When speaking about the transfer of scientific thinking to the area of politics and morality, he is not concerned with the transfer of scientific theories and methods but with the application of the 
experimental spirit - which, in his view, is embodied in the most adequate way in the natural sciences - to social conflicts.

But while, according to Dewey, the natural sciences can look back upon considerable successes, the development of socio-scientific research is still at its very beginning, in terms of its methodological foundations as well as its results. In order to successfully approximate scientific methods, the mixing of social sciences with moral categories has to be broken up first. According to Dewey: "Approach to human problems in terms of moral blame and moral approbation, of wickedness or righteousness, is probably the greatest single obstacle now existing to development of competent methods in the field of social subject-matter." (LW 12: 489). Consequently, Dewey demands breaking with a language that strongly separates science and morality, similar to breaking with Scholasticism's neo-Aristotelian world view, which enabled the success story of natural sciences.

What, then, is the essence of the scientific method that Dewey would like to see transferred to the field of politics and morality? In The Quest for Certainty Dewey lists three characteristics of experimental research:

The first is the obvious one that all experimentation involves overt doing, the making of definite changes in the environment or in our relation to it. The second is that experiment is not a random activity but is directed by ideas which have to meet the conditions set by the need of the problem including the active inquiry. The third and concluding feature, in which the other two receive their full measure of meaning, is that the outcome of the directed activity is the construction of a new empirical situation in which objects are differently related to one another, and such that the consequences of directed operations form the objects that have the property of being known. (LW 4: 70)

Transferred to the social sciences, the following demands arise for Dewey: Firstly, the process of research is to be understood as a reciprocal relationship of theory and practice. The starting point of each social inquiry is a concrete problem, while the goal is the creation of an unproblematic situation which should, however, differ from the previous, problem-causing state. Consequently, the objective is not a return to, but rather a more or less extensive transformation of the situation and thus the growth of experience. The path to this result consists of phases of theoretical reflection and practical implementation that are interlocked in such a way that they mutually enlighten each other. These phases of practical implementation are to be understood as experiments until a satisfying solution for the problem is found. Here Dewey attaches particular significance to the understanding of research as an open and revisable process. During this process, "facts" (which for Dewey includes values and belief systems) are not simply regarded as given but considered as means that either promote or hinder the transformation of a situation: "[F]acts have to be determined in their dual function as obstacles and as resources; that is, with reference to operations of negation (elimination) and affirmation." (LW 12: 493).

31 Secondly, the cultural embeddedness of all research must also be considered. The meaning of "facts" arises from the context in which they are situated. Furthermore, the evaluations, which are meant to result from an examination of these "facts," need to remain rooted in that context, or from the outset they risk falling short of the problematic situation's transformation. Thus, Dewey's method of social criticism is immanent to the extent that he views values and norms as constitutive elements of a problematic situation. As such, they serve as resources for the treatment of problems, 
but they can also act as essential triggers of a problematic situation. Accordingly, Dewey is clearly no socialist utopian: social change for him always concerns practical problems to be solved and his criticism, precisely, is not conducted externally. For instance, in his critical engagement with liberalism, he does not simply wish to overthrow the liberal social order but instead aims at its radical transformation from within. In short: Dewey advocates "day by day" change that is orientated towards actual life-world problems and that, nonetheless, does not exhaust itself in mere reformism (Dewey 1973: 62).

Thirdly, values and norms thus have to be considered in the social inquiry, and this in a double sense: On the one hand Dewey rejects the ideal of a value-free social science; as far as it is considered an experimental science, that is, an activity that aims at transformation, it must carry out evaluations and must itself classify results as desirable or undesired (LW 12: 490). On the other hand, value convictions are social facts that can likewise generate a problem constellation. This applies not least to the individual property rights, which the later Dewey, as shown above, regards as a substantial obstacle for comprehensive social reconstruction. But in contrast to Honneth, for whom "basic fundamental rights" are firmly written into the grammar of modern society, Dewey opposes the acceptance of allegedly eternal or unimpeachable values. ${ }^{6}$

The background to this criticism of seemingly eternal values is Dewey's "genetic method," which Thelma Lavine summarizes as "argu[ing] from the time-bound, culture-bound character of problematic situations and the responses they evoke: a response in the form of a religious, or philosophic, or political view, which was adequate to a past situation or to a situation in a different cultural context" (Lavine 1985: 64). What this genetic method means becomes especially clear in the already mentioned discussion of Dewey's critique of classical liberalism in Individualism old and New (LW 5). There he argues that Locke's liberalism in his time was an adequate response to the encrusted structures of feudalism, but is only a hindrance in the face of current problems that require stronger government action. The decisive gain of this genetic or historical perspective thus consists in the de-dogmatization of social institutions, such as the right to property, which at a certain point in time may well have been conducive to liberal goals, but under changed conditions can be reversed.

This problematization of fundamental values can and is supposed to take place in a rational and thus scientific way, as Hilary and Ruth Anna Putnam state in following Dewey:

As an end-in-view a situation is evaluated both in terms of the means necessary to its realization and in terms of its future consequences. All these evaluations are rational in the sense defined by Dewey. Dewey does not deny that we value things, states of affairs, and so on, without consideration of their status as means or consequences, but he holds that while such valuings, like the qualitative observations of everyday life, may and do initiate inquiry, they are not its outcome. What has just been said undermines the fact/value distinction by showing that paradigmatic value judgments are as amenable to rational-experiential warrant as are means consequences judgments. (Putnam \& Putnam 1994: 205-6)

If it is indeed those same values that stand in the way of the solution to a problem and consequently the growth of experience, then the social inquiry must address these convictions and possibly attempt to change them. If the aspired goals cannot be realized with the available means or if costs turn out to be too high, then these same 
objectives become revisable. "Ends have to be adjudged (evaluated) on the basis of the available means by which they can be attained just as much as existential materials have to be adjudged (evaluated) with respect to their function as material means of effecting a resolved situation." (LW 12: 490).

Consequently, the idea of a dialectical connection between means and ends is a central point of Dewey's philosophy. Moreover, he never considers values to be final, but only "ends-in-view," which are as such constituents of a continuum of means and purposes. Dewey's backdrop for this reflection is the fact that in uncertain situations, not only the means available for achieving a certain end can prove to be problematic, but also the ends themselves. This can be the case, for instance, if an end can only be achieved with quite considerable costs or if the necessary means are simply not available. In such constellations, the ends of actions and the values standing behind them are called into question.

Therefore, there are no predetermined, unchangeable ends that acting individuals can use for orientation during their search for solutions to problems. Nevertheless, this search is not entirely blind. Firstly, one must remember the pragmatist maxim stating that, in problematic situations, we are always dealing with a concrete doubt. This means that there definitely is a broad reservoir of convictions and means from which the acting individual can draw. But it is equally possible to imagine situations in which recourse to seemingly unproblematic convictions is impossible. In constellations of such kind, a search for new means, but possibly also for new ends or a new configuration of ends must be conducted; as a result, new convictions are created. One example of this is a new understanding of individual rights and, in particular, a different conception of property oriented towards common welfare.

As mentioned, Dewey's most crucial thought is that such a creation will lead to a growth of experience, so long as it points beyond what already exists. He ascribes a normative-aesthetic quality to this growth of experience (see Joas 1997: 139-41). In his Studies in Logical Theory, Dewey correspondingly characterizes as follows the benchmark that the success or failure of the thinking process must be able to be measured against: "The measure of its success, the standard of its validity, is precisely the degree in which the thinking actually disposes of the difficulty and allows us to proceed with more direct modes of experiencing, that are forthwith possessed of more assured and deepened value." (MW 2: 299-300). Consequently, thinking is in no way limited to a passive adaptation of the agent to a problematic environment.

In his religious-philosophical treatise A Common Faith (LW 9), Dewey distinguishes between three forms of interplay that the human organism experiences with his environment in light of problematic situations. The first and most simple form is "accommodation." This designates a passive adaptation to the respective situation; we adjust to the new situation and align our actions accordingly. The second type is what Dewey calls "adaptation." In this case, we don't adjust to our environment, but we actively act upon it in order to shape it according to our goals. The third and highest form of transformation, however, is "adjustment." Here, we neither adjust to our environment nor do we transform it according to our intentions, but our goals and values themselves are up for revision: "It is a change of will conceived as the organic plenitude of our being, rather than any special change in will." (LW 9: 13; emph. i. o.). Consequently, it is the individual or a community of individuals with her/their fundamental value concepts that are at the heart of the transformation. Dewey labels 
exactly those experiences during which the fundamental points of orientation for action are generated or revised as religious experiences. ${ }^{7}$

This idea of a fundamental transformation of values can also be transferred onto social communities, which is exactly what Dewey's concept of "social reconstruction" aimed at (Campbell 1984). That is to say that overcoming problematic situations can equally be about fundamental social structures - for instance, that of property ownership - or about social value patterns - such as widespread individualism. Against this backdrop, however, the criticism formulated by Rahel Jaeggi (2018: 249), stating that Dewey's concept would fail "with regard to the higher level character and the reflexive nature of the problems" of extensive forms of life, is not convincing. For Jaeggi it is important that Dewey conceptualizes problems as "inderterminate situation" because this notion is embedded in a contextual whole and, therefore, problems must be conceived not as isolated phenomena but as a disturbance of the whole system. However, Jaeggi perceives Dewey's problem-solving procedure as overly optimistic when it comes to the solving of problems because, in her understanding, Dewey conceptualizes problems only as fractures that enter into a principally intact social world.

However, his model of social inquiry especially provides a reflexivity that enables a problematization of "forms of life" with respect to their problematic conditions. In his model Dewey counted, as mentioned before, first of all on deliberative practices or, in his words, on the method of intelligence:

As a matter of fact, the pragmatic theory of intelligence means that the function of mind is to project new and more complex ends - to free experience from routine and from caprice. Not the use of thought to accomplish purposes already given either in the mechanism of the body or in that of the existent state of society, but the use of intelligence to liberate and liberalize action, is the pragmatic lesson. [...] A pragmatic intelligence is a creative intelligence, not a routine mechanic. (MW 10: 44-4)

Without Dewey himself having explicitly emphasized this aspect, the creativity of intelligence also includes its reflexivity. This reflexivity includes the reflection of its own limits, leading Dewey to a stronger connection of theory and praxis - an element that Honneth's methodology clearly disregards. In our context, this means that in certain problematic situations it is possible to recognize that social reforms cannot be demanded by scientific methods alone. ${ }^{8}$ Rather, overcoming the capitalist regime of inequality requires genuinely political methods, which for Dewey, as mentioned above, include not only classic forms of party politics but also (mass) strikes. Strikes would then be a means to come closer to the ideal of democratic socialism; and democratic socialism would then be a means to realize the liberal values of individuality and freedom not only for a few, but for as many people as possible.

\section{The Superiority of Pragmatism}

To conclude, we would like to summarize the results of this comparison in three principles which establish the superiority of Dewey's pragmatic method of problemsolving in comparison to Honneth's normative reconstruction: Firstly, Dewey avoids Honneth's socio-ontological optimism and rather assumes a deficient status quo; secondly, these dysfunctionalities are placed at the center of his method; and thirdly, 
this concept is embedded in a pragmatist frame of day-to-day and lifeworld experiences.

(1) Compared to Honneth's thesis of "the largely rational character of the institutional reality" (which he adopted from Hegel) and its derived goal of "conversely showing moral rationality to have already been realized in core modern institutions" (Honneth 2014: 2), Dewey draws a completely different picture of social reality. His approach does not focus on the continuity of institutions and practices but on their dynamics and their transformation. Since Dewey does not share Honneth's thesis of the correctness of those institutions and practices fundamental to societies of democratic capitalism, his demands are not limited to gradual reforms in small steps, which would be supported by a broad majority because of the insight into the supposed rationality of the existing institutions. He rather demands a considerably more radical transformation of society. According to our understanding, this conflictual dynamic of social realities is not merely a historical mirror of the dismissal of the context in which Dewey's texts of the 1930's arose, but a direct result of his methodological reflections.

(2) Dewey's model of continuous problem-solving arises from the basic pragmatist assumption of the continuity of the world of experience and the environment. Problems are identified, experimentally processed, and finally solved, before these solutions become potential new problems over time. This takes account of the assumption that problems are precisely not epiphenomena of an otherwise intact social world, but are rooted in their center. Honneth's attempt in The Idea of Socialism to transfer the aspect of Dewey's problem-processing into his own model is, however, short-sighted, as he limits his reception of Dewey's approach mainly to the aspect of its experimentalism and thereby neglects the aspect of problem-identification, which actually precedes the former. By turning away from the possible reception of Dewey's method of social inquiry he misses out on the chance to integrate an element into his theory that broaches exactly the subject of this at least potentially fundamental issue. Unlike Honneth, who refuses the possibility that central social structures can be fundamentally dysfunctional, Dewey conceives the social world precisely not as basically unimpaired. It should be clear that for Dewey problems are not to be resolved ultimately but rather serve to identify concrete problems of a society that is inherently conflictual. Particularly with Dewey's notion of growth in mind, it becomes evident that problem-solving for him is not a process to be completed but always depends on the possibility of further growth and thus includes a notion of constant transformation. Since Dewey rightfully holds that there are no ultimate, unchangeable values or norms, this kind of transformation does not exhaust itself in mere reformism. Rather, ends are always dialectically entangled with their respective means and their initial problematic situation and, hence, ends themselves are always up for revision.

(3) Finally, Dewey's method of problem-solving activity is embedded in the pragmatist tradition, which takes concrete life-world experiences seriously and in that way avoids exuberant theoretical presuppositions. Rather, everyday experiences of problems and dysfunctionality are not betrayed in favor of allegedly superior theoretical insights. This is due to the fact that Dewey's methodology embraces its own reflexivity including its limits. Instead of assuming and prioritizing the fundamental rationality of institutions and practices like Honneth, Dewey's approach makes it possible to take into consideration social and political problems that can be experienced in reality. This concession makes space for the possibility that scientific methodology at some point 
might come to an end and that certain issues might instead require genuine political engagement. Because Dewey's method permits a more immediate integration of practical experiences, it is more open to new, unpredictable and radically different forms of problems that could conceivably arise and therefore open to significantly more dynamic and radical transformations.

\section{BIBLIOGRAPHY}

BETZ Joseph, (1978), “John Dewey on Human Rights," Transactions of the Charles S. Peirce Society, vol. $14,18-41$.

BORDEAU Edward, (1971), “John Dewey's Ideas about the Great Depression,” Journal of the History of Ideas, 32 (1), 67-84.

BRUNKHORST Hauke, (2001), "Kritische Theorie und Pragmatismus," in Thomas Schäfer, Udo Tietz \& Rüdiger Zill (eds.), Hinter den Spiegeln: Beiträge zur Philosophie Richard Rortys mit Erwiderungen von Richard Rorty, Frankfurt-a.-Main, Suhrkamp, 145-61.

CAMPBell James, (1984), “Dewey's Method of Social Reconstruction," Transactions of the Charles S. Peirce Society, vol. 20, 363-93.

DEWEY John, (1967), The Early Works (1882-1898), 5 volumes, ed. by Jo Ann Boydston, Carbondale, Southern Illinois University Press, (cited as EW with volume number).

DEWEY John, (1973), Lectures in China 1919-1920, Honolulu, University of Hawaï Press.

DEWEY John, (1976), The Middle Works (1899-1924), 15 volumes, ed. by Jo Ann Boydston, Carbondale, Southern Illinois University Press (cited as MW with volume number).

DEWEY John, (1981), The Later Works (1925-1952), 17 volumes, ed. by Jo Ann Boydston, Carbondale, Southern Illinois University Press (cited as LW with volume number).

FORST Rainer, HARTMANN Martin, JAEGGI Rahel \& Martin SAAR (eds.), (2009), Sozialphilosophie und Kritik. Axel Honneth zum 60. Geburtstag, Frankfurt-a.-Main, Suhrkamp.

FRASER Nancy \& Axel HONNETH, (2003), Redistribution or Recognition? A Political-Philosophical Exchange, London/New York, Verso.

FREYENHAGEN Fabian, (2017), “Was ist orthodoxe Kritische Theorie," Deutsche Zeitschrift für Philosophie, 65 (3), 456-69.

HARTMANN Martin, (2003), Die Kreativität der Gewohnheit: Grundzüge einer pragmatistischen Demokratietheorie, Frankfurt-a.-Main, Campus Verlag.

HONNETH Axel, (1995), The Struggle for Recognition: The Moral Grammar of Social Conflicts, Cambridge, Ma., The MIT Press.

HONNETH Axel, (1998a), "Democracy as Reflexive Cooperation: John Dewey and the Theory of Democracy Today," Political Theory, 26 (6), 763-83. 
HONNETH Axel, (1998b), “Between Proceduralism and Teleology: An Unresolved Conflict in Dewey's Moral Theory," Transactions of the Charles S. Peirce Society, 34 (3), 689-711.

HONNETH Axel, (2003), “Redistribution as Recognition: A Response to Nancy Fraser," in Nancy Fraser \& Axel Honneth, Redistribution or Recognition? A Political-Philosophical Exchange, London/New York, Verso, 110-97.

Honneth Axel, (2007), "Pathologies of the Social: The Past and Present of Social Philosophy," in Id., Disrespect: The Normative Foundations of Critical Theory, Cambridge, Polity Press, 3-48.

HONNETH Axel, (2009), “A Social Pathology of Reason: On the Intellectual Legacy of Critical Theory," in Id., Pathologies of Reason: On the Legacy of Critical Theory, New York, Columbia University Press, 10-42.

HONNETH Axel, (2014), Freedom's Right: The Social Foundations of Democratic Life, New York, Columbia University Press.

HONNETH Axel, (2017), The Idea of Socialism: Towards a Renewal, Cambridge, Polity Press.

HORKHEIMER Max, (2013 [1947]), Eclipse of Reason, London, Bloomsbury.

JAEGGI Rahel, (2018), Critique of Forms of Life, Cambridge, Ma., Harvard University Press.

JAEGGI Rahel \& Tilo WESCHE (eds.), (2009), Was ist Kritik?, Frankfurt-a.-Main, Suhrkamp.

JOAS Hans, (1997), The Creativity of Action, Chicago, Chicago University Press.

JOAS Hans, (2001), The Genesis of Values, Chicago, Chicago University Press.

JÖRKE Dirk, (2003), Demokratie als Erfahrung. John Dewey und die politische Philosophie der Gegenwart, Wiesbaden, Westdeutscher Verlag.

JÜTTEN Timo, (2015), “Is the Market a Sphere of Social Freedom?," Critical Horizons, 16 (2), 187-203.

LAVINE Thelma Z., (1985), “John Dewey and the Founders: Human Nature and Politics," Works and Days, 3 (1), 53-75.

LEE Mordecai, (2015), The Philosopher-Lobbyist: John Dewey and the People's Lobby, 1928-1940, Albany, Ny., State University of New-York Press.

LEPOLD Kristina, (2017), “Axel Honneths Neubegründung der kritischen Gesellschaftstheorie. Die kritische Theorie der Anerkennung," in Sven Ellmers \& Philip Hogh (eds.), Warum Kritik? Begründungsformen kritischer Theorie, Weilerswist, Velbrück Wissenschaft, 281-300.

LIVINGSTON Alexander, (2017), “Between Means and Ends: Reconstructing Coercion in Dewey's Democratic Theory," American Political Science Review, 111, 522-34.

MILls C. Wright, (1964), Sociology and Pragmatism: The Higher Learning in America, New York, PaineWhitman Publishers.

NG Karen, (2019), “Social Freedom as Ideology," Philosophy and Social Criticism, 45 (7), 795-818.

NULLMEIER Frank, (2013), "Rekonstruktion als Methode? Evaluative Gesellschaftsanalyse bei Axel Honneth," Neue Politische Literatur, 58 (1), 21-30.

PIKETTY Thomas, (2020), Capital and Ideology, Cambridge, Ma., The Belknap Press of Harvard University Press.

PUTNAM Hilary \& Ruth Anna PUTNAM, (1994), "Dewey's Logic: Epistemology as Hypothesis," in James Conant (ed.), Hilary Putnam: Words and Life, Cambridge, Ma., Harvard University Press, 198-220. 
ROTH Robert, (1962), John Dewey and Self-Realization, Englewood Cliffs, S. J. Prentice-Hall, Inc.

SÄRKELÄ Arvi, (2017), “Immanent Critique as Self-Transformative Practice. Hegel, Dewey and Contemporary Critical Theory," Journal of Speculative Philosophy, 31 (2), 218-30.

SÄRKELÄ Arvi, (2018), “Kritische Theorie,” in Georg Festl (ed.), Handbuch Pragmatismus, Stuttgart, J. B. Metzler, 281-9.

SÄRKELÄ Arvi \& Arto LAITINEN, (2019), “Between Normativism and Naturalism: Honneth on Social Pathology," Constellations, 26 (2), 286-300.

schAUB Jörg, (2015), “Misdevelopments, Pathologies, and Normative Revolutions. Normative Reconstruction as Method of Critical Theory," Critical Horizons, 16 (2), 107-30.

SIMICH Jerry L. \& Tilman RICK, (1978), "Radicalism vs. Liberalism: C. Wright Mills' Critique of John Dewey's Ideas," American Journal of Economics \& Sociology, 37 (4), 413-30.

STAHL Titus, (2013), Immanente Kritik: Elemente einer Theorie sozialer Praktiken, Frankfurt/New York, Campus Verlag.

STEARS Marc, (2010), Demanding Democracy: American Radicals in Search of a New Politics, Princeton, Princeton University Press.

WESTBROOK Robert B., (1991), John Dewey and American Democracy, Ithaca, Cornell University Press.

\section{NOTES}

1. Arvi Särkelä (2017) opposes this opinion and highlights the strong points of immanent criticism in the style of Dewey (and Hegel) compared to contemporary Critical Theory, in particular Jaeggi (2018).

2. Honneth had indeed already highlighted previously, during his debate with Nancy Fraser (Fraser \& Honneth 2003), that the notion of struggles for recognition should, despite its intersubjective focus, not remain on the anthropological level; however, the method of normative reconstruction as a "strategy of picking up on values and ideas already institutionalized in society" (Honneth 2014: 63) can also be interpreted as Honneth's attempt to address this gap left open in his earlier work.

3. Some of the here-mentioned critics take up a notably more open-minded position towards Honneth's early work than towards the method of normative reconstruction presented in Freedom's Right. For Nullmeier (2013: 29f.) and Ng (2019: 806), this assessment is based mostly on Honneth's notion of recognition (Honneth 1995); Fabian Freyenhagen (2017: 466f.) likewise perceives more potential in Honneth's early work, although rather in the latter's notion of pathology than in his notion of recognition (Honneth 2007, 2009).

4. However, Nullmeier also clearly reveals that, for him, the primary problem lies not in the aforementioned aspect, but rather in the method's flawed understanding of immanence. Because the problem of violated immanence is of greater importance for him, he does not feel responsible to answer this thesis.

5. While in his early work $(2007,2009)$ Honneth still operates with the concept of pathology, which concerns the state of societies as such, he relinquishes this concept in Freedom's Right in favor of a division of labor with "societal aberrations." By doing so, he robs himself of an allencompassing "umbrella term" (Särkelä \& Laitinen 2019: 286), which would be able to capture exactly such general social wrongs and refer to a comprehensive transformation of society (see ibid.) 
6. However, it can be argued that Dewey's concept of growth is a kind of super value: "We set up this and that end to be reached, but the end is growth itself. To make an end a final goal is but to arrest growth." (LW 7: 306; emph. i. o.). On the normative substance of Dewey's concept of growth and its implications for democratic theory, see below and Jörke (2003).

7. Similar to how Dewey proceeds in his book on art, he attempts to radically broaden the scope of religious experiences in his philosophy of religion as well and opposes the view that equates religiosity with the belief in transcendental deities (see in more detail Joas 2001).

8. To that extent, he is in this point in agreement with C. Wright Mills's (1966) criticism of the limits of the scientific method (see also Simich \& Rick 1978).

\section{ABSTRACTS}

This article compares Axel Honneth's method of normative reconstruction with John Dewey's method of problem-solving. We argue that Dewey's method is more open to "radical" measures of social transformation because it does not bear Honneth's inherent conservative implications. Dewey's "more radical" measures include, in particular, demands for a socialist transformation of the economy, whereas Honneth's approach leads to mere reformist proposals within the existing property system, such as the introduction of a minimum wage. We situate this juxtaposition in the more recent discussion on the methodology of critical theories and argue that, despite the recent turn of Critical Theorists towards Dewey's pragmatic philosophy, the potential of the latter has so far been largely neglected.

\section{AUTHORS}

\section{DIRK JÖRKE}

Technische Universität Darmstadt

joerke[at]pg.tu-darmstadt.de

\section{PHILIPP WAGENHALS}

Technische Universität Darmstadt

philipp.wagenhals[at]stud.uni-frankfurt.de 